May 2002 • NREL/CP-520-31443

\title{
Solar-Grade Silicon from Metallurgical-Grade Silicon Via lodine Chemical Vapor Transport Purification
}

\section{Preprint}

T.F. Ciszek, T.H. Wang, M.R. Page, R.E. Bauer, and M.D. Landry

To be presented at the $29^{\text {th }}$ IEEE PV Specialists Conference New Orleans, Louisiana May 20-24, 2002
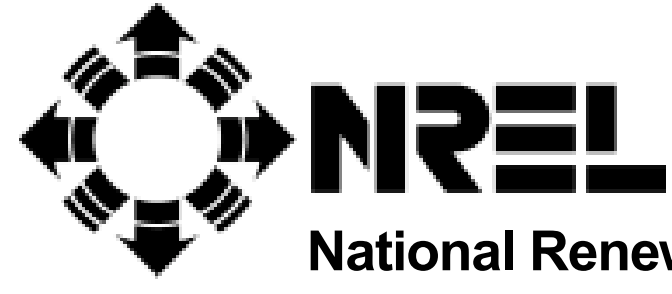

National Renewable Energy Laboratory

1617 Cole Boulevard

Golden, Colorado 80401-3393

NREL is a U.S. Department of Energy Laboratory

Operated by Midwest Research Institute $\bullet$ Battelle $\bullet$ Bechtel

Contract No. DE-AC36-99-G010337 


\section{NOTICE}

The submitted manuscript has been offered by an employee of the Midwest Research Institute (MRI), a contractor of the US Government under Contract No. DE-AC36-99G010337. Accordingly, the US Government and MRI retain a nonexclusive royalty-free license to publish or reproduce the published form of this contribution, or allow others to do so, for US Government purposes.

This report was prepared as an account of work sponsored by an agency of the United States government. Neither the United States government nor any agency thereof, nor any of their employees, makes any warranty, express or implied, or assumes any legal liability or responsibility for the accuracy, completeness, or usefulness of any information, apparatus, product, or process disclosed, or represents that its use would not infringe privately owned rights. Reference herein to any specific commercial product, process, or service by trade name, trademark, manufacturer, or otherwise does not necessarily constitute or imply its endorsement, recommendation, or favoring by the United States government or any agency thereof. The views and opinions of authors expressed herein do not necessarily state or reflect those of the United States government or any agency thereof.

Available electronically at http://www.osti.gov/bridge

Available for a processing fee to U.S. Department of Energy and its contractors, in paper, from:

U.S. Department of Energy

Office of Scientific and Technical Information

P.O. Box 62

Oak Ridge, TN 37831-0062

phone: 865.576 .8401

fax: 865.576.5728

email: reports@adonis.osti.gov

Available for sale to the public, in paper, from:

U.S. Department of Commerce

National Technical Information Service

5285 Port Royal Road

Springfield, VA 22161

phone: 800.553 .6847

fax: 703.605.6900

email: orders@ntis.fedworld.gov

online ordering: http://www.ntis.gov/ordering.htm

Printed on paper containing at least $50 \%$ wastepaper, including $20 \%$ postconsumer waste 


\title{
SOLAR-GRADE SILICON FROM METALLURGICAL-GRADE SILICON VIA IODINE CHEMICAL VAPOR TRANSPORT PURIFICATION
}

\author{
T.F. Ciszek*, T.H. Wang, M.R. Page, R.E. Bauer, and M.D. Landry \\ National Renewable Energy Laboratory, Golden, CO 80401 USA
}

\begin{abstract}
In an atmospheric-pressure "open" reactor, $\mathrm{Sil}_{2}$ transfers from a hot $\left(>1100^{\circ} \mathrm{C}\right)$ Si source to a cooler $\left(>750^{\circ} \mathrm{C}\right)$ Si substrate and decomposes easily via $2 \mathrm{Sil}_{2} \rightarrow$ $\mathrm{Si}+\mathrm{Sil}_{4}$ with up to $5 \mu \mathrm{m} / \mathrm{min}$ deposition rate. Sil 4 returns to cyclically transport more $\mathrm{Si}$. When the source is metallurgical-grade $\mathrm{Si}$, impurities can be effectively removed by three mechanisms: (1) differing free energies of formation in forming silicon and impurity iodides; (2) distillation; and (3) differing standard free energies of formation during deposition. Distillation has been previously reported. Here, we focused on mechanisms (1) and (3). We made feedstock, analyzed the impurity levels, grew Czochralski single crystals, and evaluated crystal and photovoltaic properties. Cell efficiencies of $9.5 \%$ were obtained. Incorporating distillation (step 2) should increase this to a viable level.
\end{abstract}

\section{INTRODUCTION}

A projection by one of the large polysilicon manufacturers indicates that PV demand for reject $\mathrm{Si}$ from the electronics industry will exceed the supply (8000 metric tons/yr) by a factor of 2 to 4 by the year 2010 [1]. Of the more than $300 \mathrm{MW}$ of photovoltaic modules sold per year, about $85 \%$ are made from silicon. Si PV manufacturers have repeatedly expressed concern about the future supply of low-cost feedstock as this market continues to grow by more than $30 \% / y e a r$. The issue is to supply solar grade silicon (SoG-Si) feedstock with the necessary purity $(\sim 99.999 \%)$ at an acceptable cost. We report research on a new approach for producing SoG-Si from metallurgical-grade silicon (MG-Si) based on atmospheric pressure iodine vapor transport (APIVT).

\section{ATMOSPHERIC PRESSURE IODINE VAPOR TRANPORT PURIFICATION OF SILICON}

Our work on the growth of thin-layer $\mathrm{Si}$ at atmospheric pressure by APIVT [2] led us to explore its applicability to MG-Si purification. lodine reacts with Si to form $\mathrm{Sil}_{4}$, which reacts further with silicon at high temperatures to form $\mathrm{Sil}_{2}$. $\mathrm{Sil}_{2}$ decomposes easily with a silicon deposition rate $>5 \mu \mathrm{m} / \mathrm{min}$ when the source Si temperature is $\sim 1200^{\circ} \mathrm{C}$ and the substrate temperature is approximately $1000^{\circ} \mathrm{C}$. When MG-Si is used as the source material, impurities can be effectively removed in several ways:
(1) During the initial reaction between iodine and MG-Si, the formation of impurity iodides will be advanced or retarded (relative to the formation of $\mathrm{Sil}_{2}$ ) depending on their free energies of formation. (2) Purification of $\mathrm{Sil}_{4}$ by distillation in a cyclic process will cause metal iodides with vapor pressure lower than that of $\mathrm{Sil}_{4}$ to remain at the bottom of a distillation tower, and those with higher vapor pressure to rise to the top. For example, at one atmosphere, carbon tetra iodide boils at $19^{\circ} \mathrm{C}$ higher than $\mathrm{Sil}_{4}$ and phosphorous tri-iodide at $63^{\circ} \mathrm{C}$ lower. These large differences permit easy separations. (3) During the deposition of silicon from $\mathrm{Sil}_{2}$, most metal iodides have a large negative value of standard free energy of formation, so they are more stable than $\mathrm{Sil}_{2}$ and $\mathrm{Sil}_{4}$. These iodides will form readily in the gas phase, but have only a small tendency to be reduced again in the deposition zone. An example of this behavior is $\mathrm{All}_{3}$ [3]. The cyclic APIVT refinement process incorporating all three of these components [4] is shown in Fig. 1.

In Fig. 1, MG-Si and I are introduced into a crucible or liner at the bottom of a cold wall reactor and heated to temperature $\mathrm{T} 1$. At first, $\mathrm{T} 1$ is $\sim 500^{\circ}-1000^{\circ} \mathrm{C}$. Silicon and some impurities react with iodine to form $\mathrm{Sil}_{4}$ and impurity

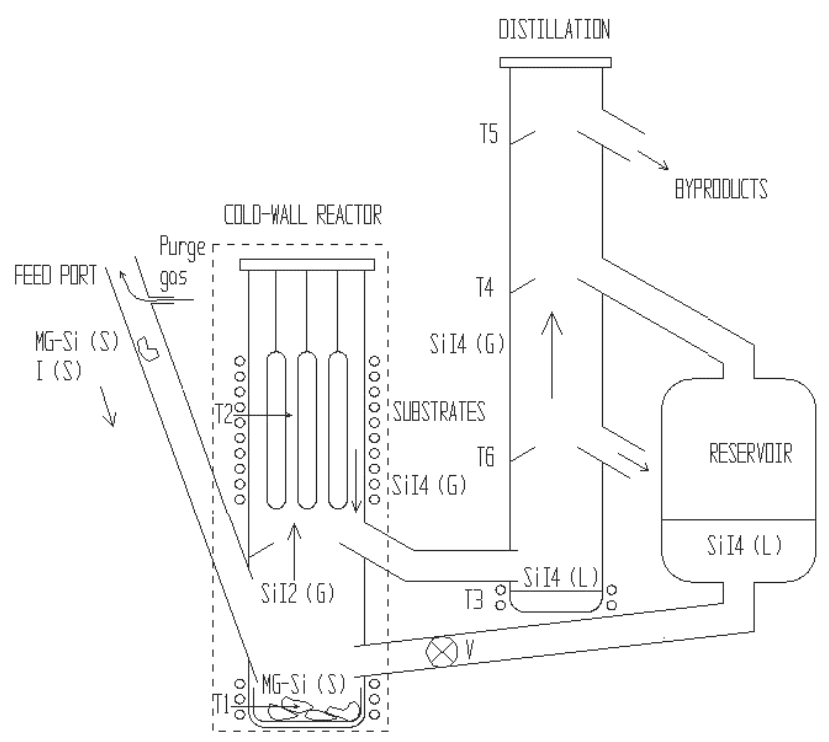

Fig. 1. Schematic of the cyclic APIVT MG-Si purification process incorporating components (1), (2), and (3) 
iodides. Some tri-iodides of $\mathrm{B}$ and $\mathrm{P}$ are removed from the distillation plate near the reactor top $\left(T \approx 120^{\circ} \mathrm{C}\right)$. The purer gases condense on the wall of the reactor and flow into the distillation tower that is heated at the bottom to T3 $\approx 310^{\circ} \mathrm{C}$. With most metal iodides retained in the liquid, $\mathrm{Cl}_{4}$ vaporizes and condenses on the lower and hotter distillation plate $\left(\mathrm{T} 6 \approx 205^{\circ} \mathrm{C}\right.$ ) whereas $\mathrm{Bl}_{3}$ and $\mathrm{PI}_{3}$ are collected at the highest and coolest plate $\left(T 5 \approx 120^{\circ} \mathrm{C}\right)$. The purified $\mathrm{Sil}_{4}$ is collected at the middle plate $\left(\mathrm{T} 4 \approx 185^{\circ} \mathrm{C}\right)$ and returns to the crucible/liner at the reactor bottom. After this initial start-up, the temperature in the crucible is turned up to $\mathrm{T} 1>1000^{\circ} \mathrm{C}$. The purified $\mathrm{Sil}_{4}$ further reacts with $\mathrm{Si}$ at this temperature to form $\mathrm{Sil}_{2}$, which transports from hot regions to cooler ones. $\mathrm{Sil}_{2}$ is very unstable and easily decomposes into $\mathrm{Si}$ and $\mathrm{Sil}_{4}$ at the provided substrate surfaces (high-purity silicon slim rods, tubes, etc.) heated to $\mathrm{T} 2>750^{\circ} \mathrm{C}$. The recycling $\mathrm{Sil}_{4}$ (together with additional impurity iodides) goes through the distillation process again before returning to the reactor bottom.

As MG-Si is consumed, it is replenished through a gas-purged feed port. This gas purge is above an equilibrium iodine and iodide cloud layer that forms at a height corresponding to an appropriate temperature region cooler than T2. A similar purge above the cloud in the main reactor can allow removal of deposited purified silicon, thus affording a continuous process at approximately atmospheric pressure. Volatile gases are kept in the system by the cloud layer due to condensation and gravity effects described in [2]. The entire reactor wall within the dotted frame must be kept "cold" at between $120^{\circ}-700^{\circ} \mathrm{C}$ to prevent silicon deposition on the walls.

$\mathrm{Sil}_{4}$ distillation [step (2) above] has been previously studied $[5,6]$, so we focused on investigating purification by the initial reaction between iodine and MG-Si and by the final deposition of silicon from $\mathrm{Sil}_{2}$ [steps (1) and (3) above]. First we grew $\sim 100-\mu \mathrm{m}$-thick epitaxial layers of $\mathrm{Si}$ by APIVT from a MG-Si source onto high-purity, singlecrystal substrates. Impurity levels in these layers are shown in Fig. 2. They were analyzed by secondary ion mass spectroscopy (SIMS) and glow discharge mass spectroscopy (GDMS). Also shown are the MG-Si source material impurity levels determined by GDMS. The vertical lines show the permissible range of impurities in SoG$\mathrm{Si}$, dependent on growth method, with the upper limit for slow directional solidification and near equilibrium segregation, whereas the lower limit is for growth with little or no effective segregation, such as is the case for some ribbon growth processes. The selective APIVT pick-up, transport, and deposition of silicon reduced the concentration of all major impurities by more than several orders of magnitude, except for $B$ (and $P$, not shown). Addition of the distillation step (2) should reduce $B$ and $P$ to the SoG-Si specification.

\section{CRYSTAL GROWTH AND ANALYSIS}

Multiple large-area substrates in the form of concentric quartz cylinders were used for APIVT growth of thick layers from a MG-Si source. These layers were harvested and melted as feedstock for Czochralski (CZ) crystal growth and analysis. Figure 3 is a picture of a small $<100>$ CZ single crystal grown from this material. The melt was clean, and no unusual problems were observed in growing crystals from the APIVT purified MG-Si feedstock. Table I shows the GDMS analysis of impurities in the MG-Si source and in the CZ crystal grown from APIVT-purified silicon. All metallic impurities are below the detection limits of the GDMS technique (values preceded by <), which, in the worst case, was 0.005 ppma. The predominant non-metallic impurities were $O$ (17.6 ppma), C (14.3ppma), P (6.8 ppma), and B (4.2 ppma). Thus, the crystal was highly compensated and mostly ntype, with $\rho=0.3 \Omega-\mathrm{cm}$ near the tail end. However, a small region of the seed end was p-type with a resistivity of $0.4 \Omega-\mathrm{cm}$. Diagnostic solar cells $2-\mathrm{mm} \times 2-\mathrm{mm}$ in size were fabricated using a seed end wafer; they had an efficiency of $9.5 \%$, as shown in Fig. 4, compared to an electronic-grade CZ-grown control cell efficiency of $13.8 \%$.

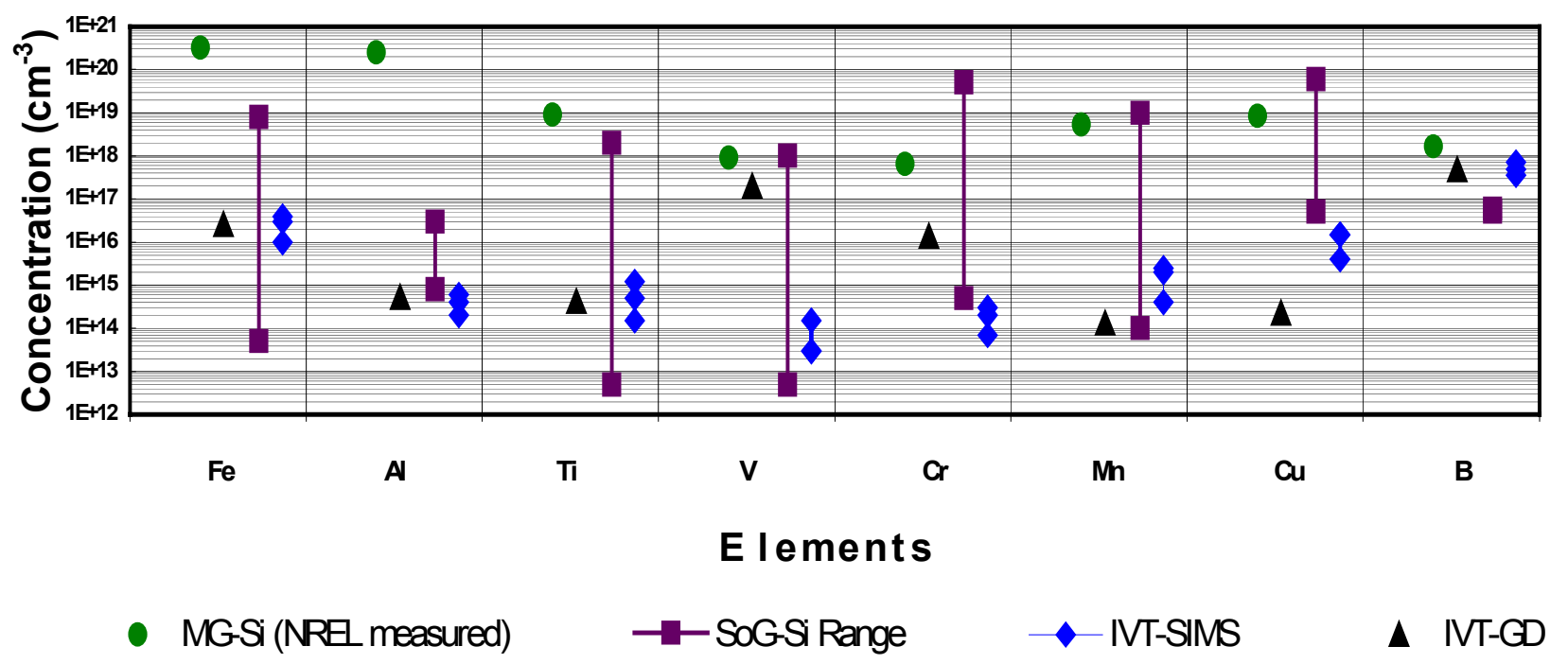

Fig. 2. Impurity contents in the MG-Si source material and in an epitaxial silicon layer grown by APIVT 


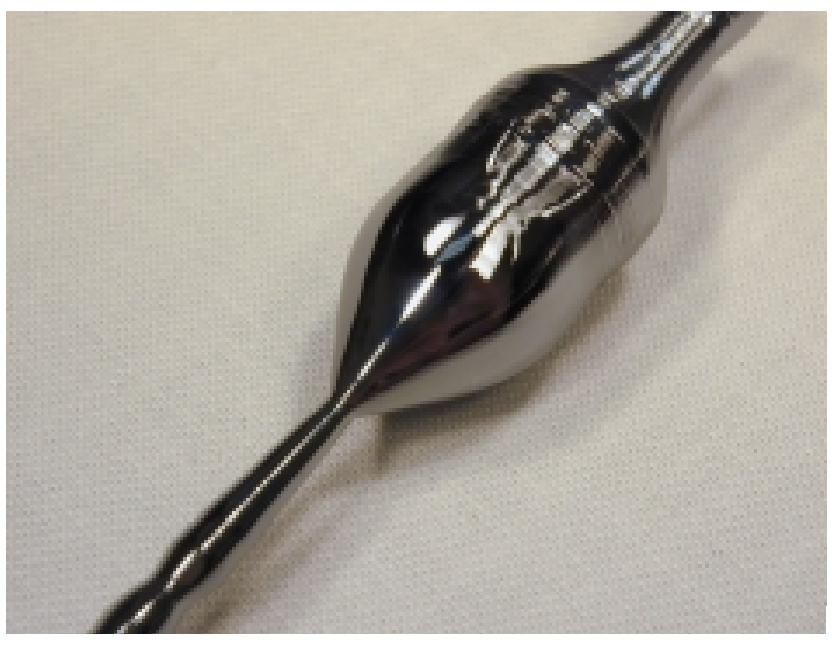

Fig. 3. A 14-mm-dia. <100> CZ crystal grown from APIVTpurified MG-Si

Table I. GDMS Analysis of Impurities in MG-Si and in a CZ Crystal Grown from APIVT-Purified MG-Si (without $\mathrm{Sil}_{4}$ distillation)

\begin{tabular}{lll}
\hline & $\begin{array}{l}\text { CZ-Si from } \\
\text { Element }\end{array}$ & $\begin{array}{l}\text { MG-Si source } \\
\text { Appma] }\end{array}$ \\
\hline $\mathrm{B}$ & 4.157 & 14.548 \\
$\mathrm{C}$ & 14.264 & 107.565 \\
$\mathrm{O}$ & 17.554 & 66.706 \\
$\mathrm{Mg}$ & $<0.001$ & 8.204 \\
$\mathrm{Al}$ & $<0.005$ & 520.458 \\
$\mathrm{Si}$ & Matrix & Matrix \\
$\mathrm{P}$ & 6.801 & 21.762 \\
$\mathrm{~S}$ & $<0.044$ & 0.096 \\
$\mathrm{~K}$ & $<0.007$ & $<0.036$ \\
$\mathrm{Ca}$ & $<0.007$ & 44.849 \\
$\mathrm{Ti}$ & $<0.001$ & 47.526 \\
$\mathrm{~V}$ & $<0.001$ & 143.345 \\
$\mathrm{Cr}$ & $<0.001$ & 19.985 \\
$\mathrm{Mn}$ & $<0.001$ & 19.938 \\
$\mathrm{Fe}$ & $<0.005$ & 553.211 \\
$\mathrm{Co}$ & $<0.002$ & 0.763 \\
$\mathrm{Ni}$ & $<0.002$ & 22.012 \\
$\mathrm{Cu}$ & $<0.001$ & 1.724 \\
$\mathrm{Zn}$ & $<0.002$ & 0.077 \\
$\mathrm{As}$ & $<0.002$ & 0.007 \\
$\mathrm{Sr}$ & $<0.0003$ & 0.353 \\
$\mathrm{Zr}$ & $<0.0003$ & 2.063 \\
$\mathrm{Mo}$ & $<0.001$ & 0.790 \\
$\mathrm{I}$ & $<0.0002$ & $<0.001$ \\
$\mathrm{Ba}$ & $<0.0002$ & 0.266 \\
$\mathrm{~W}$ & $<0.0003$ & 0.024 \\
\hline & &
\end{tabular}

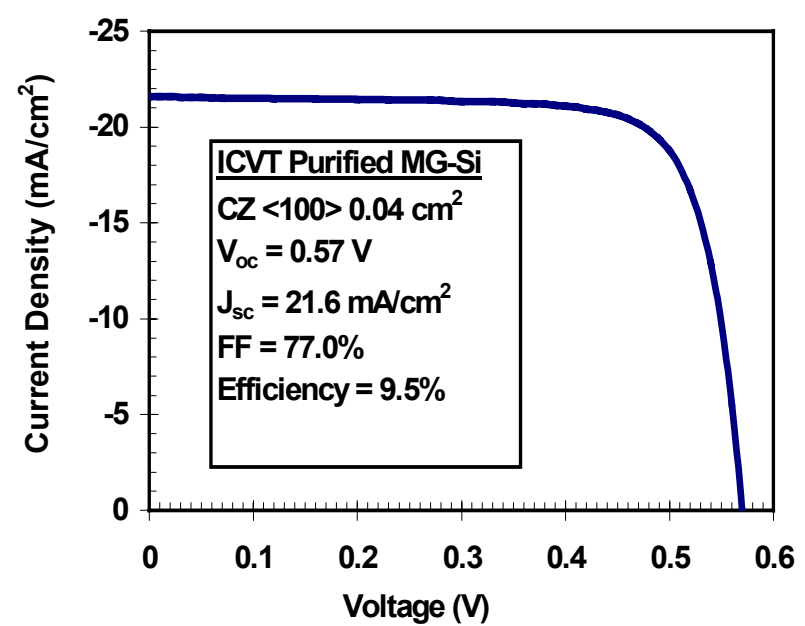

Fig. 4. Diagnostic solar cell parameters for a wafer from a $<100>$ CZ crystal grown using APIVT-purified MG-Si

The cell parameter comparison between the $\mathrm{CZ}$ crystal grown from APIVT-purified feedstock silicon and the control CZ wafer grown from electronic-grade silicon is given in Table 2, and internal quantum efficiency is shown in Fig. 5.

Table 2. Cell Parameters for CZ Grown from APIVTPurified Silicon and a Control CZ Wafer.

\begin{tabular}{lll}
\hline Parameter & $\begin{array}{l}\mathrm{CZ} \\
\text { control }\end{array}$ & $\begin{array}{l}\mathrm{CZ} \\
\text { from APIVT Si }\end{array}$ \\
\hline Efficiency & 13.8 & 9.5 \\
$\mathrm{~V}_{\text {oc }}($ Volts $)$ & 0.59 & 0.57 \\
$\mathrm{~J}_{\mathrm{sc}}\left(\mathrm{mA} / \mathrm{cm}^{2}\right)$ & 29.9 & 21.6 \\
Fill Factor $(\%)$ & 78.4 & 77.0 \\
\hline
\end{tabular}

From internal quantum efficiency and reflectance data for a cell made from CZ grown using APIVT feedstock, we deduced a diffusion length of $8 \mu \mathrm{m}$. The high degree of compensation and high levels of $B$ and $P$ likely influence the properties of the material. Incorporating the distillation step [step (2)] will probably be necessary to obtain better performance from the APIVT-purified feedstock.

\section{SUMMARY AND DISCUSSION}

APIVT MG-Si purification is attractive because of its fast deposition rates and atmospheric-pressure operation. The later provides the potential for continuous operation with relatively easy input of source material and withdrawal of product. We demonstrated reduction of metallic impurities by several orders of magnitude using steps (1) and (3) of this process. We were able to grow small $C Z$ crystals from the limited amount of Si produced in our labscale APIVT reactor. The resistivity was $\sim 0.4 \Omega-\mathrm{cm}$, but 


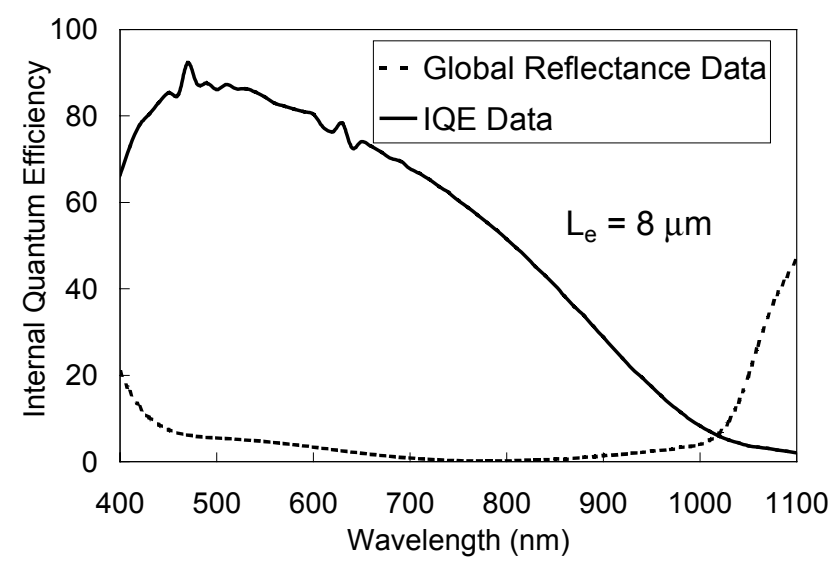

Fig. 5. Internal quantum efficiency (\%) and reflectance (\%) vs. wavelength

compensated with both $\mathrm{B}$ and $\mathrm{P}$ present in relatively large quantities. This resulted in a relatively low solar cell efficiency of $9.5 \%$ and low diffusion length of $8 \mu \mathrm{m}$. The carbon levels in the material are also higher than desired for reliable single crystal growth on a large scale.

Coupled with previously studied $\mathrm{Sil}_{4}$ distillation [step (2)] to remove $B, P$, and C, APIVT MG-Si purification could become a practical and economical method for manufacturing SoG-Si feedstock. Earlier work in the silicon/iodine system by C.S. Herrick [6] and G.H. Moates [5] used iodine to purify silicon in the sequential steps: $\mathrm{Si}+\mathrm{I}$ $>\mathrm{Sil}_{4}>$ purified $\mathrm{Sil}_{4}$ (by e.g. distillation, solution recrystallization, or zone-refining/sublimation) $>$ thermo-decomposition of $\mathrm{Sil}_{4}$ into $\mathrm{Si}$ under a low pressure of $\sim 3 \mathrm{~mm} \mathrm{Hg}$. Such a process is inherently slow and uneconomical, because $\mathrm{Sil}_{4}$ can only be decomposed in low pressure, and requires a vacuum system. A key advance is provided by our approach that utilizes the disproportionation reaction: $\mathrm{Si}+$ purified $\mathrm{Sil}_{4}>\mathrm{Sil}_{2}>$ purified $\mathrm{Sil}_{4}+$ purified $\mathrm{Si}$, to deposit silicon at atmospheric pressure, similar to the operating principles in our previous thin-layer silicon growth [2], but with the addition of built-in $\mathrm{Sil}_{4}$ purification steps.

\section{ACKNOWLEDGEMENTS}

We thank members of NREL's Measurements and Characterization team for providing the SIMS analysis. NREL's Director's Discretionary Research and Development (DDRD) Program provided support for this research.

\section{REFERENCES}

[1] J. Maurits, in: Proceedings of the $8^{\text {th }}$ NREL Workshop on Crystalline Silicon Solar Cell Materials and Processes, Ed: B.L. Sopori (August 1998 NREL/CP-520-25232), pp. 10-17.

[2] T.H. Wang and T. F. Ciszek, "Growth of Large-Grain Silicon Layers by Atmospheric lodine Vapor Transport," J. Electrochem. Soc. 147 (2000) pp. 1945-1949.

[3] R. Glang and B.W. Kippenhan, Impurity Introduction during Epitaxial Growth of Silicon, IBM Journal (July, 1960) pp. 299-301.

[4] T.H. Wang and T.F. Ciszek, "Method for Purifying Silicon," patent application in process.

[5] G.H. Moates, et al., US Patent 3006737, 1961.

[6] C.S. Herrick, US Patent 3020129, 1962. 


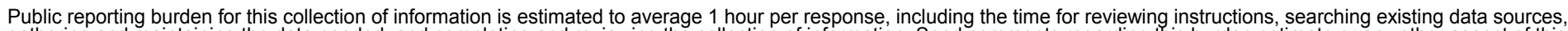

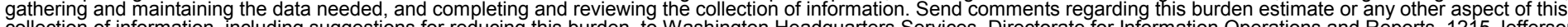
Davis Highway, Suite 1204, Arlington, VA 22202-4302, and to the Office of Management and Budget, Paperwork Reduction Project (0704-0188), Washington, DC 20503.

\begin{tabular}{|l|l|l|l|}
\hline 1. AGENCY USE ONLY (Leave blank) & $\begin{array}{l}\text { 2. REPORT DATE } \\
\text { May } 2002\end{array}$ & $\begin{array}{l}\text { 3. REPORT TYPE AND DATES COVERED } \\
29^{\text {th }} \\
\text { IEEE PVSC-Conference Paper } \\
\text { May 20-24 2002 }\end{array}$ \\
\hline
\end{tabular}

4. TITLE AND SUBTITLE

Solar-Grade Silicon from Metallurgical-Grade Silicon Via lodine Chemical Vapor Transport Purification: Preprint

6. AUTHOR(S)

T.F. Ciszek, T.H. Wang, M.R. Page, R.E. Bauer, and M.D. Landry

7. PERFORMING ORGANIZATION NAME(S) AND ADDRESS(ES)

National Renewable Energy Laboratory

1617 Cole Blvd.

Golden, CO 80401-3393

9. SPONSORING/MONITORING AGENCY NAME(S) AND ADDRESS(ES)

National Renewable Energy Laboratory

1617 Cole Blvd.

Golden, CO 80401-3393
5. FUNDING NUMBERS PVP24801

8. PERFORMING ORGANIZATION REPORT NUMBER

11. SUPPLEMENTARY NOTES

12a. DISTRIBUTION/AVAILABILITY STATEMENT

National Technical Information Service

12b. DISTRIBUTION CODE

U.S. Department of Commerce

5285 Port Royal Road

Springfield, VA 22161

13. ABSTRACT (Maximum 200 words): This conference paper describes the atmospheric-pressure in an "open" reactor, Sil ${ }_{2}$ transfers from a hot $\left(>1100^{\circ} \mathrm{C}\right)$ Si source to a cooler $\left(>750^{\circ} \mathrm{C}\right)$ Si substrate and decomposes easily via $2 \mathrm{Sil}_{2} \rightarrow \mathrm{Si}+\mathrm{Sil}_{4}$ with up to $5 \mathrm{~m} / \mathrm{min}$ deposition rate. $\mathrm{Sil}_{4}$ returns to cyclically transport more Si. When the source is metallurgical-grade Si, impurities can be effectively removed by three mechanisms: (1) differing free energies of formation in forming silicon and impurity iodides; (2) distillation; and (3) differing standard free energies of formation during deposition. Distillation has been previously reported. Here, we focused on mechanisms (1) and (3). We made feedstock, analyzed the impurity levels, grew Czochralski single crystals, and evaluated crystal and photovoltaic properties. Cell efficiencies of $9.5 \%$ were obtained. Incorporating distillation (step 2) should increase this to a viable level.

14. SUBJECT TERMS: PV; atmospheric-pressure; solar grade silicon; chemical vapor transport purification; thin-layer Si; crystal growth; impurities; quantum efficiency; SoGSi feedstock; refining/sublimation; thermo-decomposition;

17. SECURITY CLASSIFICATION OF REPORT

Unclassified
18. SECURITY CLASSIFICATION OF THIS PAGE Unclassified
19. SECURITY CLASSIFICATION OF ABSTRACT Unclassified
15. NUMBER OF PAGES

16. PRICE CODE

20. LIMITATION OF ABSTRACT

UL 